\title{
Generation of New Benanomicin Analogues by Biotransformation Using Escherichia coli Expressing Actinomycete Cytochrome P450
}

\author{
Hiroyuki Kumagai, Maya Umekita, Ryuichi Sawa, Yoshikazu Takahashi, \\ Akira Arisawa, Kunio Isshiki, Yoshio Nishimura, Yuzuru Akamatsu
}

Received: February 25, 2008 / Accepted: May 28, 2008

(C) Japan Antibiotics Research Association

\begin{abstract}
Benanomicins were found as antifungal antibiotics from the culture of an actinomycete with potent antifungal activities in vitro and in vivo. We aimed to generate derivatives superior to benanomicin A by biotransformation using Escherichia coli constructed with bacterial P450 expression system. We found transformation of benanomicin A into two derivatives, 10hydroxybenanomicin $\mathrm{A}$ and 11-O-demethylbenanomicin $\mathrm{A}$ by one of the P450-expressed strains which harbored a plasmid carrying a CYP105C1-homologous gene. Unexpectedly, the biotransformed compounds showed weak antifungal activities in vitro compared with those of benanomicin $\mathrm{A}$.
\end{abstract}

Keywords benanomicin, biotransformation, P450, actinomycete, E. coli

Benanomicin A, possessing a benzo(a)naphthacenequinone skeleton, was isolated from the culture of Actinomadura spadix MH193-16F4 from a soil sample, and represented the broad antimicrobial spectrum against a wide range of fungi including pathogens of endemic and opportunistic mycoses [1 3]. Benanomicin A showed the potent antifungal activities in animal models using Candida albicans, Aspergillus fumigatus and Cryptococcus neoformans [4, 5]. Moreover, benanomicin A showed antiviral activities [6, 7]. The mechanism of action of benanomicin A was deduced to bind to fungal cell wall, but it has not been confirmed clearly [8,9]. On the other hand, pradimicins were found as antifungal compounds at almost the same time of the discovery of benanomicins [10 12]. The structures of pradimicins are closely related to those of benanomicins and the mechanism of action in their antifungal activity was clarified to bind specifically to Dmannoside of the fungal cell surface in the presence of calcium $[13,14]$.

Benanomicin A was obtained from the culture broth of Actinomadura spadix MH193-16F4 using the methods mentioned in the previous paper [1].

In our previous study, we developed the versatile expression system for bacterial P450 genes using Escherichia coli BL21(DE3) as a host. Based on the system, we created the bacterial P450 expression library which serves the rapid biotransformation screening with help of co-expressed Pseudomonas redox partner genes cam $\mathrm{AB}$ [15]. In our attempt to obtain benanomicin derivatives with improved biological activities, we took an approach to test P450-catalyzed transformation of benanomicin A by the strain of the bacterial P450 expressed E. coli, since the $\mathrm{P} 450$ s are able to catalyze monooxygenation (principally hydroxylation) to a diverse set of organic compounds. For the expression of the P450 genes in the $E$. coli BL21(DE3) strains, $25 \mathrm{ml}$ of $\mathrm{M} 9$ mix-ampicillin medium $\left(6.78 \mathrm{~g} /\right.$ liter $\mathrm{Na}_{2} \mathrm{HPO}_{4}, 3.0 \mathrm{~g} /$ liter
H. Kumagai (Corresponding author), M. Umekita, R. Sawa, Y. Takahashi, Y. Nishimura, Y. Akamatsu: Microbial Chemistry Research Center, 3-14-23 Kamiosaki, Shinagawa-ku, Tokyo 1410021, Japan, E-mail: kumagai@m-cleantec.com
H. Kumagai (Corresponding author), A. Arisawa, K. Isshiki: Bioresource Laboratories, Mercian Corp., Nakaizumi 1808, Iwata, Shizuoka 438-0078, Japan 
$\mathrm{KH}_{2} \mathrm{PO}_{4}, 0.5 \mathrm{~g} /$ liter $\mathrm{NaCl}, 1.0 \%$ casamino acid, $0.4 \%$ Dglucose, $0.1 \mathrm{mM} \mathrm{CaCl}, 1.0 \mathrm{mM} \mathrm{MgCl}_{2}, 0.1 \mathrm{mM} \mathrm{FeSO}_{4}$, $20 \mu \mathrm{g} / \mathrm{ml}$ thymine and $50 \mu \mathrm{g} / \mathrm{ml}$ ampicillin) was inoculated with $0.5 \mathrm{ml}$ of the culture over night, and was cultured further at $37^{\circ} \mathrm{C}$. When the optical density at $660 \mathrm{~nm}$ reached 0.7 to 0.8 , isopropyl-thio- $\beta$-D-galactoside (IPTG) and 5 -aminolevulinic acid were added to the culture at the final concentration of 0.1 and $0.5 \mathrm{mM}$ respectively, and the cells were grown for a further 20 hours at $22^{\circ} \mathrm{C}$. The cells were harvested by centrifugation at $6,000 \mathrm{~g}$ for 10 minutes at $4{ }^{\circ} \mathrm{C}$, and the pellet was resuspended in $5.0 \mathrm{ml}$ of CV2 buffer $(2.0 \%$ glycerol, $50 \mathrm{mg} / \mathrm{ml}$ ampicillin, $0.1 \mathrm{mM}$ IPTG and $50 \mathrm{mM}$ phosphate buffer at $\mathrm{pH}$ 7.4). One hundred microgram of benanomicin A was dissolved in $20 \mu \mathrm{l}$ of $\mathrm{H}_{2} \mathrm{O}$, and was added to the $0.5 \mathrm{ml}$ of the cell suspension at a final concentration of $200 \mu \mathrm{g} / \mathrm{ml}$. After incubation using a rotary shaker under $200 \mathrm{rpm}$ at $28^{\circ} \mathrm{C}$ for 24 hours, the reaction products were extracted with $0.5 \mathrm{ml}$ of $1-\mathrm{BuOH}$ at $\mathrm{pH}$ 2.5. The organic layer was evaporated to dryness under reduced pressure using a centrifugal evaporator. The residue was dissolved in $0.2 \mathrm{ml}$ of $\mathrm{MeOH}$ for HPLC analysis (Waters 2695 HPLC system, CAPCELL PAK UG120 $5.0 \mu \mathrm{m}$, column $4.6 \times 100 \mathrm{~mm}$, Shiseido Co. LTD., Japan, flow rate $1.0 \mathrm{ml} /$ minute, column temperature $40^{\circ} \mathrm{C}$, diode array detection in 15 minutes) with acetonitrile concentration linear-gradient in water containing $0.1 \%$ TFA from $20 \%(\mathrm{v} / \mathrm{v})$ to $90 \%(\mathrm{v} / \mathrm{v})$.

The biotransformation was carried out with over 200 strains of the P450 library. Subsequent HPLC analysis of the extracts from the reaction mixture revealed that one strain BL21(DE3)/pCP55-camAB converted benanomicin A to new compounds, and the UV spectra in HPLC analysis showed new peaks similar to those of benanomicin A (Fig. 1). Then, we performed a large-scale microbial conversion using this strain to clarify the structure and biological activities of the newly formed compounds.

The P450-expressing strain, BL21(DE3)/pCP55-camAB, was inoculated into $2.0 \mathrm{ml}$ of $\mathrm{M} 9$ medium in test tube and cultured under $200 \mathrm{rpm}$ at $37^{\circ} \mathrm{C}$ for 3 hours to give an optical density reading of about 0.8 at $660 \mathrm{~nm}$. Two hundred microliters of the culture were inoculated into $225 \mathrm{ml}$ of M9 medium in a 500-ml Erlenmyer flask and cultured under $125 \mathrm{rpm}$ at $37^{\circ} \mathrm{C}$ for 3 hours to give an optical density reading of about 0.8 at $660 \mathrm{~nm}$. IPTG and 5aminolevulinic acid were added to the culture at the final concentration of 0.1 and $0.5 \mathrm{mM}$ respectively, and cultured at $22^{\circ} \mathrm{C}$ for 24 hours. Ten milliliters of benanomicin A $\left(5.0 \mathrm{mg} / \mathrm{ml}\right.$ in $\mathrm{H}_{2} \mathrm{O}$ ) and $12 \mathrm{ml}$ of glycerin were added to the culture to $200 \mu \mathrm{g} / \mathrm{ml}$ and $5.0 \%$ respectively, and cultured at $28^{\circ} \mathrm{C}$ for 24 hours. The culture supernatant obtained by centrifugation of the culture at $12,000 \mathrm{rpm}$ at $4^{\circ} \mathrm{C}$ for 15 minutes was adjusted to $\mathrm{pH} 2.5$ with $1.0 \mathrm{M} \mathrm{HCl}$ and extracted with equal volume of $1-\mathrm{BuOH}$. The extract was evaporated to dryness under reduced pressure, and the resultant residue was dissolved in DMF. The solution was placed in a refrigerator over night, and the resultant DMFinsoluble materials such as proteins were removed by centrifugation at 3,000 rpm for 20 minutes. The supernatant was evaporated to dryness under reduced pressure and dissolved in the solvent composed with 1-BuOH - MeOH -

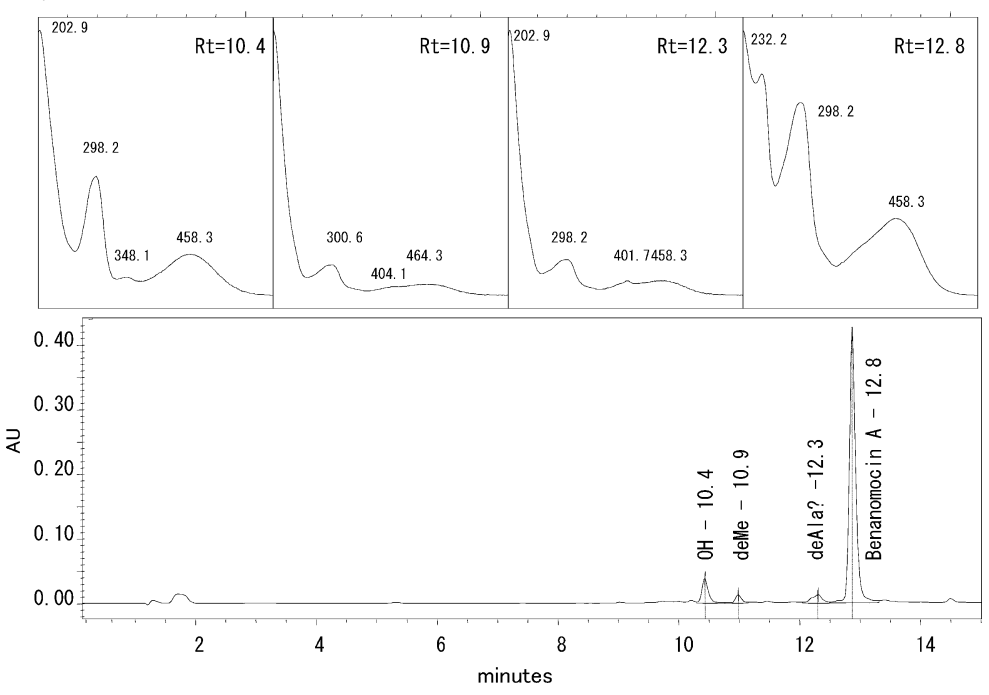

Fig. 1 HPLC analysis of the extract from bioconversion of benanomicin A using a Escherichia coli transfected an actonomycete P450 gene.

UV spectra for each of the four compounds are shown at the top of the figure. 
$0.2 \mathrm{M} \mathrm{NH}_{4} \mathrm{OH}(4: 1: 5)$. The solution was subjected to a Centrifugal Partition Chromatography (CPC). The chromatography was performed using CPC apparatus (Senshu Scientific Co. LTD., Japan) with a solvent system of $1-\mathrm{BuOH}-\mathrm{MeOH}-\mathrm{H}_{2} \mathrm{O}(4: 1: 5)$ by ascending mode to remove untransformed benanomicin $\mathrm{A}$ from the extract. The fractions containing the compound which was eluted at 12.3 minutes in the HPLC analysis were collected. Its structure was presumed to be dealaninyl derivative of benanomicin A which was known previously [16], since this compound showed $m / z 755(\mathrm{M}-\mathrm{H})^{-}$in the mass spectrum smaller than 827 of molecular weight of benanomicin A. We supposed that this compound was converted from benanomicin A not by $\mathrm{P} 450$ but by enzymes such as peptidases of $E$. coli. The partially purified benanomicin $\mathrm{A}$ analogues were further purified using the CPC apparatus with a solvent system of $\mathrm{CHCl}_{3}$ $\mathrm{MeOH}-0.1 \% \mathrm{AcOH}$ aq $(5: 6: 4)$ by ascending mode. Two analogues of benanomicin A were purified and collected as free forms. These structures of the benanomicin analogues were clarified as 10-hydroxybenanomicin A (1, retention time was 10.4 minutes) and 11-O-demethylbenanomicin A (2, retention time was 10.9 minutes) as mentioned below. The conversion ratios of the two analogues from benanomicin A were 1.5 and 3.0\%, respectively. The P450 gene on the plasmid pCP55-camAB, which was responsible for the conversion, had been amplified by PCR from the genomic DNA of an unidentified actinomycete strain previously isolated from a soil sample in our laboratory. As primers designed based on the sequence of a streptomycete P450 gene choP encoding CYP105C1 [17] had been used for the amplification of the gene, the gene showed a high homology to choP ( $>98 \%$ identify at the amino acid

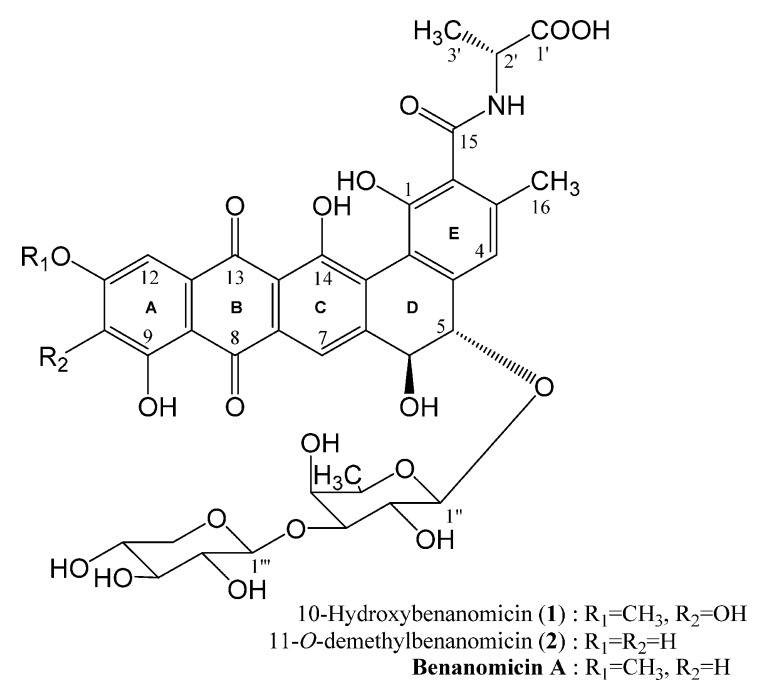

Fig. 2 Structures of benanomicin $A$ and its analogues. sequence level) encoding CYP105C1. We designated the P450 gene $\operatorname{cph} P$ ( $\underline{c} h o \underline{P}$-homologous- $\underline{\mathbf{P}} 450)$. The sequence data of $c p h P$ can be found in the DNA database of Gen Bank/EMBL/DDBJ with the accession number AB425822.

${ }^{1} \mathrm{H}$ - and ${ }^{13} \mathrm{C}-\mathrm{NMR}$, DEPT, HMQC and HMBC spectra of 1 were measured using a JEOL JNM-ECA600 apparatus (JEOL Ltd., Japan) and compared with those of benanomicin A. The assignments established by these spectra were summarized in Table 1 . The chemical shifts of ${ }^{1} \mathrm{H}$ - and ${ }^{13} \mathrm{C}$-NMR of $\mathbf{1}$ and benanomicin A were quite similar except for those of A-ring. Among them, the C-10 was completely different from each other; C-10 $(\delta$ 106.9) of benanomicin A was shifted downfield $(\delta$ 141.4) and an exchangeable proton at $\delta 10.4$ newly observed in $\mathbf{1}$. The molecular formula of $\mathbf{1}, \mathrm{C}_{39} \mathrm{H}_{41} \mathrm{NO}_{20}$, was established by HRESI-MS (JMS-T100LC apparatus, JEOL Ltd., Japan), which possesses one more oxygen atom compared with benanomicin A. These results suggested that $\mathbf{1}$ was oxygenated at position 10 of benanomicin A. The results of the HMBC experiments shown in Fig. 3 also supported the structure.

The structure of $\mathbf{2}$ was determined by the same procedure described above. The molecular formula of $\mathbf{2}, \mathrm{C}_{38} \mathrm{H}_{39} \mathrm{NO}_{19}$, was established by HRESI-MS, which differed from that of
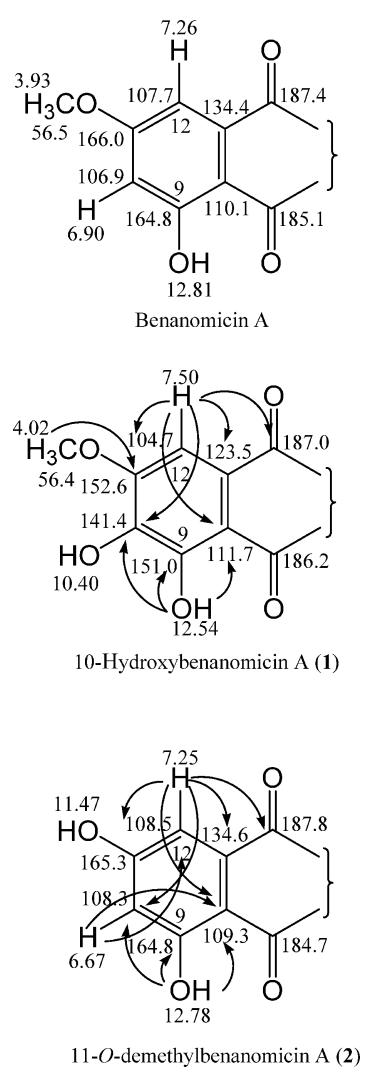

Fig. 3 Partial long-range coupling of benanomicin A and its analogues. 
Table $1 \quad{ }^{1} \mathrm{H}$ - and ${ }^{13} \mathrm{C}-\mathrm{NMR}$ data of benanomicin $\mathrm{A}$ and its analogues

\begin{tabular}{|c|c|c|c|c|c|c|}
\hline \multirow{2}{*}{ Position } & \multicolumn{2}{|c|}{ 10-Hydroxybenanomicin A (1) } & \multicolumn{2}{|c|}{ 11-O-demethylbenanomicin A (2) } & \multicolumn{2}{|r|}{ Benanomicin A } \\
\hline & ${ }^{13} \mathrm{C}$ & ${ }^{1} \mathrm{H}$ (multiplicity, $\mathrm{J} \mathrm{Hz}$ ) & ${ }^{13} \mathrm{C}$ & ${ }^{1} \mathrm{H}$ (multiplicity, $\mathrm{J} \mathrm{Hz}$ ) & ${ }^{13} \mathrm{C}$ & ${ }^{1} \mathrm{H}$ (multiplicity $\mathrm{J} \mathrm{Hz}$ ) \\
\hline $1-\mathrm{OH}$ & & 8.60 (br) & & $8.65(\mathrm{br})$ & & $8.70(\mathrm{br})$ \\
\hline 1 & 151.0 & & 150.9 & & 151.2 & \\
\hline 2 & 127.8 & & 127.5 & & 127.6 & \\
\hline 3 & 137.4 & & 137.3 & & 137.5 & \\
\hline 4 & 118.2 & 7.19 (br) & 118.3 & 7.19 (br s) & 118.6 & 7.20 (br s) \\
\hline $4 a$ & 138.1 & & 138.0 & & 138.1 & \\
\hline 5 & 82.0 & 4.51 (br d 9.8) & 82.0 & $4.51(\mathrm{brd}, 10.2)$ & 81.7 & $4.52(\mathrm{brd}, 10.4)$ \\
\hline 6 & 72.0 & 4.56 (br) & 71.9 & $4.56(\mathrm{br})$ & 71.9 & 4.57 (br) \\
\hline $6 a$ & 147.0 & & 147.6 & & 147.7 & \\
\hline 7 & 115.4 & $8.06(b r)$ & 115.5 & 8.07 (br s) & 115.4 & 8.05 (s) \\
\hline $7 a$ & 131.3 & & 131.4 & & 131.4 & \\
\hline 8 & 186.2 & & 184.7 & & 185.1 & \\
\hline $8 a$ & 111.7 & & 109.3 & & 110.1 & \\
\hline 9 & 151.0 & & 164.8 & & 164.8 & \\
\hline $9-\mathrm{OH}$ & & 12.54 (s) & & $12.78(\mathrm{~s})$ & & 12.81 (s) \\
\hline 10 & 141.4 & & 108.3 & $6.67(d, 2.3)$ & 106.9 & $6.90(\mathrm{dd}, 1.2,2.3)$ \\
\hline $10-\mathrm{OH}$ & & 10.40 (br s) & & & & \\
\hline 11 & 152.6 & & 165.3 & & 166.0 & \\
\hline $11-\mathrm{OH}$ & & & & 11.47 (br s) & & \\
\hline $11-\mathrm{OCH}_{3}$ & 56.4 & 4.02 (s) & & & 56.5 & 3.93 (s) \\
\hline 12 & 104.7 & 7.50 (s) & 108.5 & $7.25(d, 2.3)$ & 107.7 & $7.26(\mathrm{dd}, 1.2,2.3)$ \\
\hline $12 a$ & 123.5 & & 134.6 & & 134.4 & \\
\hline 13 & 187.0 & & 187.8 & & 187.4 & \\
\hline $13 a$ & 114.6 & & 115.5 & & 115.6 & \\
\hline 14 & 156.7 & & 156.8 & & 157.1 & \\
\hline $14-\mathrm{OH}$ & & 14.36 (br) & & $13.87(\mathrm{br})$ & & $13.82(\mathrm{br})$ \\
\hline $14 a$ & 125.8 & & 125.2 & & 125.6 & \\
\hline $14 b$ & 113.7 & & 113.6 & & 113.7 & \\
\hline 15 & 166.9 & & 166.9 & & 162.0 & \\
\hline 16 & 19.1 & 2.31 (s) & 19.1 & 2.32 (s) & 19.2 & 2.33 (s) \\
\hline $1^{\prime}$ & 174.1 & & 174.0 & & 174.2 & \\
\hline $1^{\prime}-\mathrm{OH}$ & & & & $12.50(\mathrm{br})$ & & $12.53(\mathrm{br})$ \\
\hline $2^{\prime}$ & 47.7 & 4.40 (quintet, 7.2) & 47.6 & 4.40 (quintet, 7.2) & 47.7 & 4.41 (quintet, 7.3) \\
\hline $2^{\prime}-\mathrm{NH}$ & & $8.53(d, 7.2)$ & & $8.53(d, 7.2)$ & & $8.54(d, 7.3)$ \\
\hline $3^{\prime}$ & 16.9 & $1.33(d, 7.2)$ & 16.8 & $1.33(d, 7.2)$ & 16.9 & $1.34(d, 7.3)$ \\
\hline $1^{\prime \prime}$ & 104.7 & $4.64(\mathrm{brd}, 6.9)$ & 104.4 & $4.64(\mathrm{br} \mathrm{d}, 8.0)$ & 104.5 & $4.65(d, 7.0)$ \\
\hline $2^{\prime \prime}$ & 70.1 & 3.70 (br) & 70.1 & $3.72(b r)$ & 70.1 & 3.74 (br) \\
\hline $3^{\prime \prime}$ & 83.2 & $3.54(\mathrm{~m})$ & 83.1 & $3.53(\mathrm{~m})$ & 83.2 & $3.55(\mathrm{~m})$ \\
\hline $4^{\prime \prime}$ & 70.4 & $3.60(\mathrm{~m})$ & 70.1 & $3.61(\mathrm{~m})$ & 70.4 & $3.61(\mathrm{~m})$ \\
\hline $5^{\prime \prime}$ & 70.1 & $3.59(\mathrm{~m})$ & 70.3 & $3.60(\mathrm{~m})$ & 70.2 & $3.61(\mathrm{~m})$ \\
\hline $6^{\prime \prime}$ & 16.4 & $1.11(d, 6.3)$ & 16.4 & $1.11(\mathrm{~d}, 6.3)$ & 16.5 & $1.12(d, 6.3)$ \\
\hline $1^{\prime \prime \prime}$ & 105.4 & $4.41(\mathrm{brd}, 7.3)$ & 105.3 & $4.41(d, 7.8)$ & 105.4 & $4.42(d, 7.3)$ \\
\hline $2^{\prime \prime \prime}$ & 73.7 & $3.11(\mathrm{dd}, 7.3,9.0)$ & 73.6 & $3.11(\mathrm{dd}, 7.8,9.0)$ & 73.7 & $3.11(\mathrm{dd}, 7.3,8.8)$ \\
\hline $3^{\prime \prime \prime}$ & 76.1 & $3.14(t, 9.0)$ & 76.0 & $3.14(t, 9.0)$ & 76.1 & $3.15(t, 8.8)$ \\
\hline $4^{\prime \prime \prime}$ & 69.4 & $3.29(\mathrm{~m})$ & 69.4 & 3.29 (ddd, 5.6, 9.0, 10.8) & 69.5 & $3.30(\mathrm{ddd}, 5.4,8.8,11.0)$ \\
\hline \multirow[t]{2}{*}{$5^{\prime \prime \prime}$} & 65.9 & $3.07(t, 10.8)$ & 65.6 & $3.07(t, 10.8)$ & 65.7 & $3.08(t, 11.0)$ \\
\hline & & $3.70(\mathrm{dd}, 5.3,10.8)$ & & $3.70(d d, 5.6,10.8)$ & & $3.71(\mathrm{dd}, 5.4,11.0)$ \\
\hline
\end{tabular}

Chemical shifts in ppm with TMS as an internal standard. Solvent: DMSO- $d_{6}\left(25^{\circ} \mathrm{C}\right)$. 
Table 2 Antifungal activities of benanomicin A and its analogues

\begin{tabular}{|c|c|c|c|}
\hline Strains & Benanomicin A & 10-OH benanomicin $\mathrm{A}$ & 11-O-deMe benanomicin A \\
\hline Candida albicans 3147 & 6.25 & $>100$ & 25 \\
\hline Candida albicans NCCLS QC strain & 6.25 & $>100$ & 12.5 \\
\hline Candida albicans flucytosine-R NCCLS QC strain & 6.25 & $>100$ & 25 \\
\hline Candida albicans azole-R & 6.25 & $>100$ & 25 \\
\hline Candida sp. YU-1200 & 12.5 & 100 & 25 \\
\hline Candida tropicalis & 12.5 & $>100$ & 25 \\
\hline Candida pseudotropicalis & 3.13 & 25 & 6.25 \\
\hline Candida krusei & 6.25 & $>100$ & 50 \\
\hline Cryptococcus neoformans v. neof.sero A & 1.56 & 25 & 25 \\
\hline Cryptococcus neoformans & 1.6 & $>100$ & 25 \\
\hline Saccharomyces cerevisiae & 1.6 & $>100$ & 3.13 \\
\hline Trichophyton rubrum (IFO 9185) & 25 & $>100$ & $>100$ \\
\hline Trichophyton rubrum (TIMM 2659) & 25 & 25 & $>100$ \\
\hline Trichophyton asteroides 429 & 25 & $>100$ & $>100$ \\
\hline Trichophyton mentagrophytes & 25 & $>100$ & $>100$ \\
\hline Aspergillus niger & 3.13 & $>100$ & 50 \\
\hline Aspergillus fumigatus (IFO 9733) & 3.13 & $>100$ & $>100$ \\
\hline Aspergillus fumigatus (TIMM 2905) & 6.25 & $>100$ & $>100$ \\
\hline Cochliobolus miyabeanus & 12.5 & $>100$ & $>100$ \\
\hline Pyricularia oryzae & 25 & $>100$ & $>100$ \\
\hline Pellicularia filamentoza sasakii & 6.25 & 25 & 25 \\
\hline
\end{tabular}

benanomicin $\mathrm{A}$ in $\mathrm{CH}_{2}$ unit. The difference of the NMR data between 2 and benanomicin A was absence of methoxy group at position 11 in benanomicin A and was to observe an exchangeable proton at $\delta 11.47$ in 2 newly. The other chemical shifts of ${ }^{1} \mathrm{H}$ - and ${ }^{13} \mathrm{C}-\mathrm{NMR}$ of 2 and benanomicin A were almost same. These data showed that the structure of 2 was 11-O-demethylbenanomicin A. The correlations derived from the $\mathrm{HMBC}$ experiment shown in Fig. 3; from H-10 ( $\delta$ 6.67) to C-8a $(\delta 109.3), \mathrm{C}-12(\delta$ $108.5)$, from $\mathrm{H}-12(\delta 7.25)$ to $\mathrm{C}-8 \mathrm{a}, \mathrm{C}-10(\delta 108.3), \mathrm{C}-11$ $(\delta$ 165.3), C-12a $(\delta$ 134.6), C-13 ( $\delta$ 187.8), from 9-OH $(\delta$ $12.78)$ to $\mathrm{C}-8 \mathrm{a}, \mathrm{C}-9$ ( $\delta$ 164.8), C-10, supported the structure.

Antifungal activities of benanomicin A and its analogues were evaluated using an agar dilution method, and were summarized in Table 2. Benanomicin A exerted antifungal activities against a wide range of fungi. The analogues of benanomicin A failed to exert the antifungal activities superior to those of benanomicin A. Antifungal activities of 11-O-demethylbenanomicin A was weak compared with those of benanomicin A, especially against Trichophyton, Aspergillus, Cochliobolus and Pyricularia. Antifungal activities of 10-hydroxy-benanomicin A were weaker than those of 11-O-demethylbenanomicin A, and showed weak antifungal activities against some fungi such as Candida pseudotropicalis. These results suggest that the hydrogen and methoxy groups at the position 10 and 11 are necessary for exerting the potent antifungal activities in benanomicin A.

In this paper, we described that two analogues of benanomicins were produced by the biotransformation system using E. coli expressing actinomycete cytochrome P450, and showed antimicrobial activities against some fungi. While we could not generate new compound superior to benanomicin A in this study, this approach should be useful for a development of pharmaceuticals from antibiotics which are not in clinical use.

Acknowledgment We thank Dr. Kenji Nishimura (Mercian Bioresource Labs) for assistance in the sequence analysis of the cphP gene.

\section{References}

1. Takeuchi T, Hara T, Naganawa H, Okada M, Hamada M, Umezawa H, Gomi S, Sezaki M, Kondo S. New antifungal antibiotics, benanomicins $\mathrm{A}$ and $\mathrm{B}$ from an actinomycete. J Antibiot 41: 807-811 (1988)

2. Gomi S, Sezaki M, Kondo S, Hara T, Naganawa H, Takeuchi 
T. The structures of new antifungal antibiotics, benanomicins A and B. J Antibiot 41: 1019-1028 (1988)

3. Watanabe M, Hiratani T, Uchida K, Ohtsuka K, Watabe H, Inouye S, Kondo S, Takeuchi T, Yamaguchi H. The in-vitro activity of an antifungal antibiotic benanomicin $\mathrm{A}$ in comparison with amphotericin B. J Antimicrob Chemother 38: 1073-1077 (1996)

4. Ohtsuka K, Watanabe M, Orikasa Y, Inouye S, Uchida K, Yamaguchi H, Kondo S, Takeuchi T. The in-vivo activity of an antifungal antibiotic, benanomicin A, in comparison with amphotericin B and fluconazole. J Antimicrob Chemother 39: 71-77 (1997)

5. Watabe $H$, Mikuniya $T$, Inouye $S$, Abe $S$, Yamaguchi $H$, Kondo S, Takeuchi T, Klein TW, Friedman H, Yamamoto Y. Antifungal antibiotic benanomicin A increases susceptibility of Candida albicans to phagocytosis by murine macrophages. J Antibiot 49: 1221-1225 (1996)

6. Hoshino H, Seki J, Takeuchi T. New antifungal antibiotics, benanomicins $\mathrm{A}$ and $\mathrm{B}$ inhibit infection of T-cell with human immunodeficiency virus (HIV) and syncytium formation by HIV. J Antibiot 42: 344-346 (1989)

7. Kondo S, Gomi S, Ikeda D, Hamada M, Takeuchi T, Iwai H, Seki J, Hoshino H. Antifungal and antiviral activities of benanomicins and their analogues. J Antibiot 44: 1228-1236 (1991)

8. Watanabe M, Gomi S, Tohyama H, Ohtsuka K, Shibahara S, Inouye S, Kobayashi H, Suzuki S, Kondo S, Takeuchi T, Yamaguchi H. Binding of benanomicin A to fungal cells in reference to its fungicidal action. J Antibiot 49: 366-373 (1996). Erratum in: J Antibiot 49: C-1 (1996)

9. Watanabe M, Tohyama H, Hiratani T, Watabe H, Inoue $S$, Kondo S, Takeuchi T, Yamaguchi H. Mode of antifungal action of benanomicin A in Saccharomyces cerevisiae. J Antibiot 50: 1042-1051 (1997)
10. Oki T, Konishi M, Tomatsu K, Tomita K, Saitoh K, Tsunakawa M, Nishio M, Miyaki T, Kawaguchi H. Pradimicin, a novel class of potent antifungal antibiotics. J Antibiot 41: 1701-1704 (1988)

11. Tomita K, Nishio M, Saitoh K, Yamamoto H, Hoshino Y, Ohkuma H, Konishi M, Miyaki T, Oki T. Pradimicins A, B and $\mathrm{C}$ : new antifungal antibiotics. I. Taxonomy, production, isolation and physico-chemical properties. J Antibiot 43: 755-762 (1990)

12. Oki T, Tenmyo O, Hirano M, Tomatsu K, Kamei $\mathrm{H}$. Pradimicins A, B and C: new antifungal antibiotics. II. In vitro and in vivo biological activities. J Antibiot 43: 763-770 (1990)

13. Watanabe M, Nishiyama Y, Inouye S, Yamaguchi H, Kondo $\mathrm{S}$, Takeuchi T. Morphological alterations of Saccharomyces cerevisiae induced by benanomicin A, an antifungal antibiotic with mannan affinity. Microbiol Immunol 42: 365-370 (1998)

14. Igarashi $\mathrm{Y}$, Oki T. Mannose-binding quinone glycoside, MBQ: potential utility and action mechanism. Adv Appl Microbiol 54: 147-166 (2004)

15. Agematu H, Matsumoto N, Fujii Y, Kabumoto H, Doi S, Machida K, Ishikawa J, Arisawa A. Hydroxylation of testosterone by bacterial cytochromes P450 using the Escherichia coli expression system. Biosci Biotech Biochem 70: 307-311 (2006)

16. Ikeda D, Nishizuka T, Huang SP, Kondo S, Takeuchi T. Amino acid analogs of benanomicin A through desalaninebenanomicin A. J Antibiot 45: 1645-1652 (1992)

17. Horii M, Ishizaki T, Paik SY, Manome T, Murooka Y. An operon containing the genes for cholesterol oxidase and a cytochrome P-450-like protein from a Streptomyces sp. J Bacteriol 172: 3644-3653 (1990) 